\title{
Desain Perancangan E-Commerce Kain Tenun Lombok Desa Sukarara Lombok Tengah
}

\author{
Suriyati $^{1}$ \\ ${ }^{1}$ Email: suriyati1870@gmail.com \\ Prodi Ilmu Komputer, Universitas Bumigora Mataram
}

\begin{abstract}
Lombok is songket woven fabric which has embossed on cotton yarn, threads of silver or gold thread. Songket weaving craft that is learned by the women Sasak is a type of traditional weaving craft. Starting from the yarn manufacturing, dyeing, to the manufacture of woven fabrics, all done the old fashioned way. To make a yarn that will be used for weaving using natural materials, such as fiber pineapple, banana fiber, cotton, and bark. As for the dye, using natural dyes from ingredients that are also naturally anyway. To produce songket cloth of a width of $1.2 \mathrm{~m}$ and $2 \mathrm{~m}$ in length takes 2-4 weeks. Motif used in the manufacture of songket is a legacy handed down that are not allowed to diseberluaskan. It is said that the traditional songket motifs from village Lombok Sukarara reached more than 100 patterns. Nothing is recorded or drawn details, unless stored in the form of a master to learn generations to come. This study uses qualitative research aimed at understanding more deeply to a problem that is studied. This study investigates the problems in marketing and promoting traditional handicrafts woven Sasak by breaking factor in using fishbone diagrams. Woven Songket generated Lombok society is very unique, because here there is a meeting of western and eastern. Technically, the second meeting of the area led to the integration in other areas in Indonesia that did not exist. Along with the development, songket cloth or woven cloth Lombok has developed the idea, both in terms of the motive and the enrichment of the author, to give birth to works of Neat and very attractive to domestic and foreign tourists. Innovation targeted in this study is an application of e-commerce in helping to market, promote and manage sales songket online.
\end{abstract}

Keywords: E-commerce, Woven Fabrics, Lombok Sukarara

\section{PENDAHULUAN}

Indonesia adalah negara yang kaya akan suku,agama, bahasa, budaya yang berbeda-beda. Indonesia merupakan Negara kepulauan yang terdiri dari 17.508 pulau.Salah satu pulau yang ada di Indonesia adalah Pulau Lombok.Pulau yang terletak di Provinsi Nusa Tenggara Barat.Pulau Lombok yang oleh penduduk pribumi disebut juga sebagai selaparang atau gumi sasak.Pulau ini dipisahkan oleh selat Lombok dari pulau Bali dan dipisahkan oleh selat Alas dari pulau Sumbawa.Kondisi wilayah Lombok berupa dataran, perbukitan dan pergunungan. Pulau Lombok memiliki luas sekitar 4.738,65 km2, yang secara administratif terbagi menjadi 4 kabupaten dan 1 kotamadya, yaitu Kabupaten Lombok Barat, Kabupaten Lombok Tengah, Kabupaten Lombok Timur, dan Kabupaten Lombot Utara serta kotamadya Kota Mataram.Salah satu hal yang terkenal dari komunitas yang menjunjung tinggi nilai kebudayaannya ini adalah kerajinan tenun songket.Jenis kerajinan ini merupakan warisan turun temurun dari jaman nenek moyang

To Maega, 2(2), Agustus 2019 | 36 


\section{To Maega | Jurnal Pengabdian Masyarakat}

P-ISSN: 2622-6332 \& E-ISSN: 2622-6340

TOMAEGA Volume 2 Nomor 2, Agustus 2019, hlm : 36-43

mereka.Para wisatawan, baik dari dalam maupun mancanegara, sangat meminati tenun songket ini.

Kain songket Lombok adalah kain tenun yang memiliki hiasan timbul dari benang katun, benang perak atau benang emas.Bagian-bagian yang diperhitungkan sedemikian rupa sehingga membentuk komposisi dan keharmonisan warna sesuai motif yang telah ditentukan sebelumnya.Kerajinan tenun kain songket yang dipelajari oleh para perempuan suku Sasak merupakan jenis kerajinan tenun tradisional. Mulai dari proses pembuatan benang, pewarnaan, hingga pembuatan kain tenun, semua dilakukan dengan cara lama. Untuk membuat benang yang akan digunakan untuk menenun menggunakan bahan-bahan alami, seperti serat nanas, serat pisang, kapas, dan kulit kayu. Sedangkan untuk pewarna, menggunakan pewarna alami dari bahan-bahan yang juga alami pula. Untuk menghasilkan sehelai kain songket yang lebarnya 1,2 $\mathrm{m}$ serta panjangnya $2 \mathrm{~m}$ membutuhkan waktu 2-4 minggu. Sehelai kain songket dihargai Rp.300.000 sampai dengan Rp. 3.000.000.

Pada awalnya, kerajinan tenun kain songket digunakan untuk busana pesta, busana pemimpin adat, maupun busana kaum bangsawan.Namun seiring perkembangan jaman, kedudukan kain tenun songket ini meluas menjadi salah satu komoditi dari suku Sasak.Saat ini kain songket sering digunakan dalam acara-acara resmiupacara adat pernikahan ataufestival adat.Dalam acara tersebut, para pria biasanya memakai kain songket sebagai bawahanyang dipasangkan dengan baju adat Tegodek Nongkeq.Sedangkan para wanita, memadukankain songket dengan baju adat lambung sebagai selendang atau ikat pinggang pemanis busana.

Menurut seorang perempuan di DesaSukarara, salah satu Desa suku Sasak terbesar penghasil kain songket, mereka sudah belajar menenun saat beranjak remaja.Dahulu, setiap anak gadis dalam keluarga-keluarga di Sukarara diwajibkan paling tidak membuat sehelai kain songket sebelum dibolehkan menikah.Dan ada anggapan, jika perempuan Sasak sudah mahir menenun, maka ia dianggap sudah siap membina rumah tangga. Alasannya, ia dianggap sudah mampu membantu penghasilan suami kelak yang umumnya bekerja sebagai bercocok tanam.Kerajinan tenun klain songket di Pulau Lombok tersebar di beberapa wilayah diantaranya adalah Desa Sukarara, Desa Sade, dan Desa Pringasela.Namun Desa Sukarara merupakan desa penghasil kain songket terbesar yang ada di Pulau Lombok dan yang masih menjaga kebudayaan menenun kain songket.

Motif yang digunakan pada pembuatan kain tenun songket merupakan warisan turun temurun yang tidak diperbolehkan untuk diseberluaskan.Konon motif tradisional songket Lombok dari Desa Sukarara mencapai lebih dari 100 pola. Tidak ada yang dicatat atau digambar detilnya, kecuali disimpan dalam bentuk master untuk dipelajari generasi yang akan datang. ${ }^{1}$

Sebagaimana kain songket dari daerah lain di Indonesia, kain songket lombok juga memilikikeunikan tersendiri dalam motif dan warna. Cirri khas kain ini tergambar dengan motif yangbermacam-macam seperti motif ayam, simetris, pelangi, kembang empat, bunga, 


\section{To Maega | Jurnal Pengabdian Masyarakat}

P-ISSN: 2622-6332 \& E-ISSN: 2622-6340

TO MAEGA Volume 2 Nomor 2, Agustus 2019, hlm : 36-43

binatangtumbuhan dan lain-lain.Beberapa motif yang terkenal adalah subhanala, ceret penginang, ragi genep, wayang, merak, tapok kemalo, dan taman rengganis. Motif-motif tersebut mengandung makna yang mendalam.Misalnya motif keker yang berupa dua ekor burung merak yang saling berhadapan.Motif kekermelambangkan kebahagian hidup.ada juga motif binatang tokek yang bermakna keberuntungan.

Kain Tenun Songket yang dihasilkan masyarakat Lombok sangat unik, karena disini ada pertemuan barat dan timur. Secara teknis, pertemuan kedua daerah ini menghasilkan keterpaduan di daerah lain di Indonesia yang tidak ada. Seiring dengan perkembangan jaman, kain songket atau kain tenun Lombok mengalami perkembangan ide, baik dalam soal motif maupun pengayaan bahan pembuatnya, hingga melahirkan karya nan apik dan sangat diminati para wisatawan domestik maupun mancanegara.

Masalah yang dihadapi para pengrajin tenun kain songket Lombok adalah berkembang pesatnya industri tekstil, berbagai jenis kain dan motif telah mampu diciptakan perusahaan tekstil dalam dan luar negeri dengan tawaran harga yang jauh lebih murah. Walaupun demikian para wisatawan tetap meminati tenun ikat ini karena dibuat dengan bahan, alat ,cara pengolahan yang alami serta memiliki nilai budaya yang tinggi dan tentunya memiliki kualitas yang jauh lebih baik dari kain buatan pabrik biasa. Untuk meningkatkan jumlah penjualan tenun ikat ini maka perlu dibuat media pemasaran dengan berbasis e-commerceyang dapat membantu para pengerajin kain tenun songket untuk mempromosikan serta membantu dalam menjual hasil usaha mereka.

\section{METODOLOGI}

Untuk studi kasus dalam penelitian ini menggunakan salah satu UKM yang bergerak di bidang kerajinan kain tenun di Desa Sukarara.Ke depannya implementasi dari e-commerce ini dapat diterapkan secara umum untuk semua UKM kain tenun yang ada di Desa Sukara ataupun yang ada di Pulau Lombok. Dari UKM yang dijadikan objek penelitian akan dikaji permalasahan yang terdapat saat ini dalam melakukan pemasaran atau penjualan kain tenun yang ada di Desa Sukarara. Dari hasil wawancara dengan pemilik UKM dan staff marketing diketahui bahwa untuk proses penjualan kain tenun masih dilakukan secara konvensional yaitu dengan membuka took (art shop) di Desa Sukarara dan menunggu pelanggan datang. Untuk promosi dilakukan apabila ada kegiatan dari dinas koperasi setempat yang biasanya mengajak UKM untuk membuka standuntuk mempromosikan kerajinan tenun.

Penelitian ini menggunakan penelitian kualitatif yang bertujuan untuk pemahaman secara lebih mendalam terhadap suatu permasalahan yang dikaji. Alat analisis yang digunakan adalah caused and effect diagram yaitu suatu grafik yang menunjukkan hubungan antara suatu masalah dan kemungkinan penyebabnya. Diagram ini merupakan suatu model untuk menghubungkan antar penyebab dengan permasalahan yang menjadi tema penelitian.Masalah itu disebut efek (effect), dan faktor yang sangat mempengaruhinya disebut penyebab (cause).Cause-and-effect

To Maega, 2(2), Agustus 2019| 38 
diagramsangat menolong untuk mengatasi permasalahan dengan mengidentifikasi penyebabnya dan juga memberikan pemahaman terhadap efek (masalah) serta faktor-faktor yang berakibat dalam suatu proses. Diagram itu juga dikenal sebagai diagram tukang ikan (fishbone diagram) atau Ishikawa Diagram.

Cause-and-effect-diagram disebut juga sebagai diagram tulang ikan karena dibuat menyerupai tulang/rangka seekor ikan dengan katagori penyebab utama disusun membentuk seperti tulang yang dihubungkan dengan tulang belakang ikan. Guna memudahkan pengelompokkan penyebabnya (cause) terdapat beberapa katagori utama yang umum digunakan. Dalam penelitian ini pengelompokan faktor penyebab tersebut dibagi ke dalam katagori: manpower (tenaga kerja), management (manajemen), methods (metode kerja), money (uang), dan environment (lingkungan). Analisis penelitian yang ingin diidentifikasi adalah proses pemasaran dan promosi yang terdapat di UKM dalam memasarkan kain tenun. Penelitian ini ingin mengetahui permasalahan dalam memasarkan dan mempromosikan hasil kerajinan kain tenun tradisional Suku Sasak dengan cara menguraikan factor penyebab dengan menggunakan fishbone diagram. Gambar 1 berikut menjelaskan beberapa penyebab kurangnya pemasaran kain tenun tradisional suku sasak.

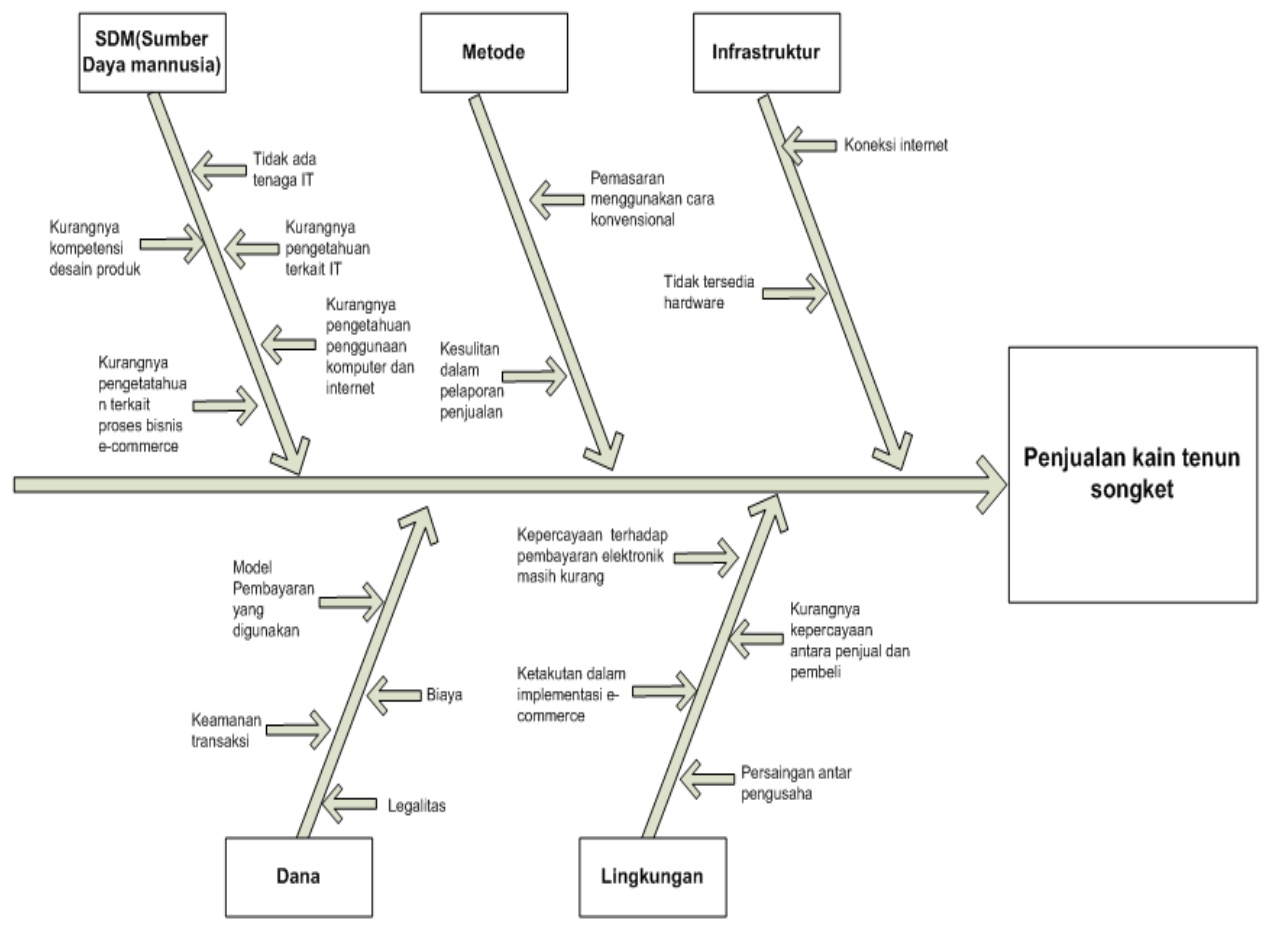

Gambar 1. Fishbone Diagram Penjualan Kain Tenun Songket

\section{Alur Pengabdian Kepada Masyarakat}

Alur kegiatan pengabdian ini dimulai dari pemilihan objek penelitian yaitu UKM kerajinan kain tenun di Desa Sukarara.selanjutnya atas dasar perumusan masalah dilakukan katagorisasi 
faktor penyebab (cause) dari permasalahan penelitian yaitu katagori manpower, management, methods, money, dan environment. Dari proses ini dilakukan penyelarasan visi sehingga terbangun pemahaman yang sama dengan teknik "bertanya mengapa" secara berulang untuk mengetahui akar masalah dari setiap katagori tersebut yang kemudian digambarkan dalam fishbone diagram. Hasil dari perunutan maslaah dengan fishbone diagram selanjutnya akan menjadi bahan penelitian untuk memberikan solusi terhadap permasalahan yang ada. Gambar 2 memberikan gambaran terhadap alur penelitian yang digunakan.

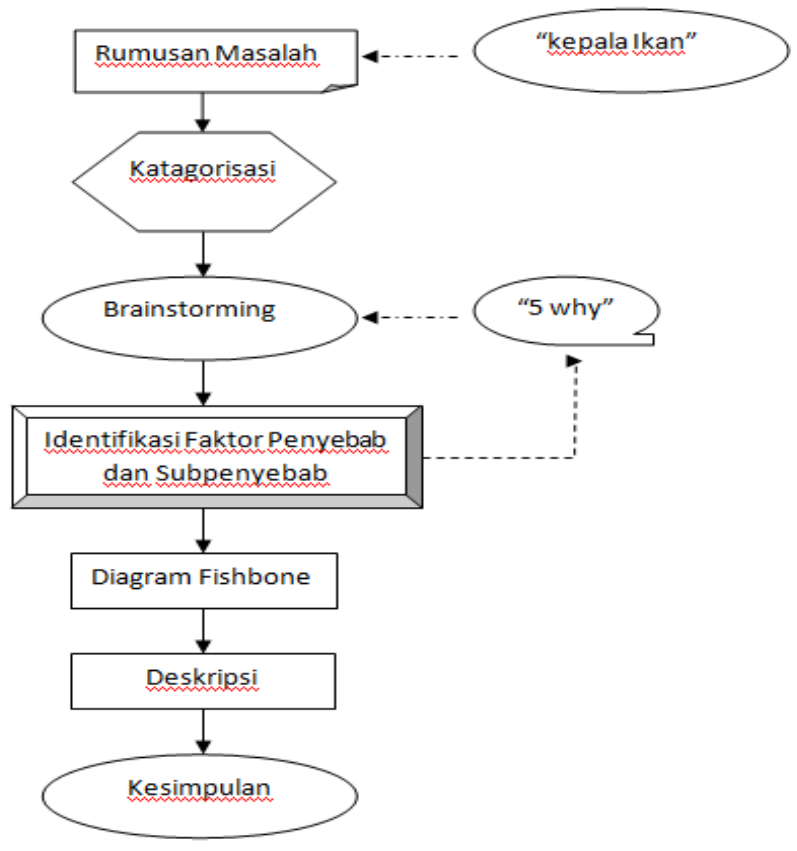

Gambar 2 Alur Penelitian

\section{HASIL DAN PEMBAHASAN}

Hasil dan pembahasan yang akan dicapai yaitu sebagai berikut:

- Terciptanya aplikasi e-commerce berbasis website

- Terimplementasinya aplikasi e-commerce untuk membantu memasarkan serta melakukan penjualan kain tenun tradisional suku sasak.

- Inovasi yang ditargetkan dalam penelitian ini adalah sebuah penerapan e-commerce dalam membantu memasarkan, melakukan promosi dan melakukan pengelolaan penjualan kain tenun songket secara online.

- E-Commerce merupakan salah satu cara yang dapat dilakukan oleh pelaku Usaha Kecil Menengah (UKM) untuk memasarkan produknya untuk dapat memperluas akses pasar. Pemasaran melalui e-commerce membuat pelaku bisnis Usaha Kecil Menengah dapat langsung berkomunikasi dengan pembelinya sehingga mereka dapat memperoleh keuntungan yang lebih besar. E-commerce untuk pemasaran produk Usaha Kecil Menengah

To Maega, 2(2), Agustus 2019| 40 


\section{To Maega | Jurnal Pengabdian Masyarakat}

P-ISSN: 2622-6332 \& E-ISSN: 2622-6340

TO MAEGA Volume 2 Nomor 2, Agustus 2019, hlm : 36-43

(UKM) dapat memperoleh manfaat serta keuntungan karena lebih murah dan efisien. Selain itu e-commerce juga memiliki akses tanpa batas, saat sebuah bisnis memiliki alamat di internet, apa yang ditampilkan dalam internet dapat diakses oleh pengunjung dari belahan dunia manapun.

- Bagi bisnis, e-commerce merupakan peluang untuk menjangkau pasar yang luas, $e$ commerce dapat memperpendek jarak geografis dan melintasi batasan waktu. Dengan pemasaran yang konvensional, pemilik UKM dapat melayani pembeli selama hari kerja dan jam kerja. Sedangkan dengan menggunakan e-commerce, pembeli dengan bebas dapat melihat-lihat produk dan membeli produk yang diinginkan selama 24 jam.

- Contoh Gambar kain tenun songket Lombok yang dipasarkan seperti berikut:
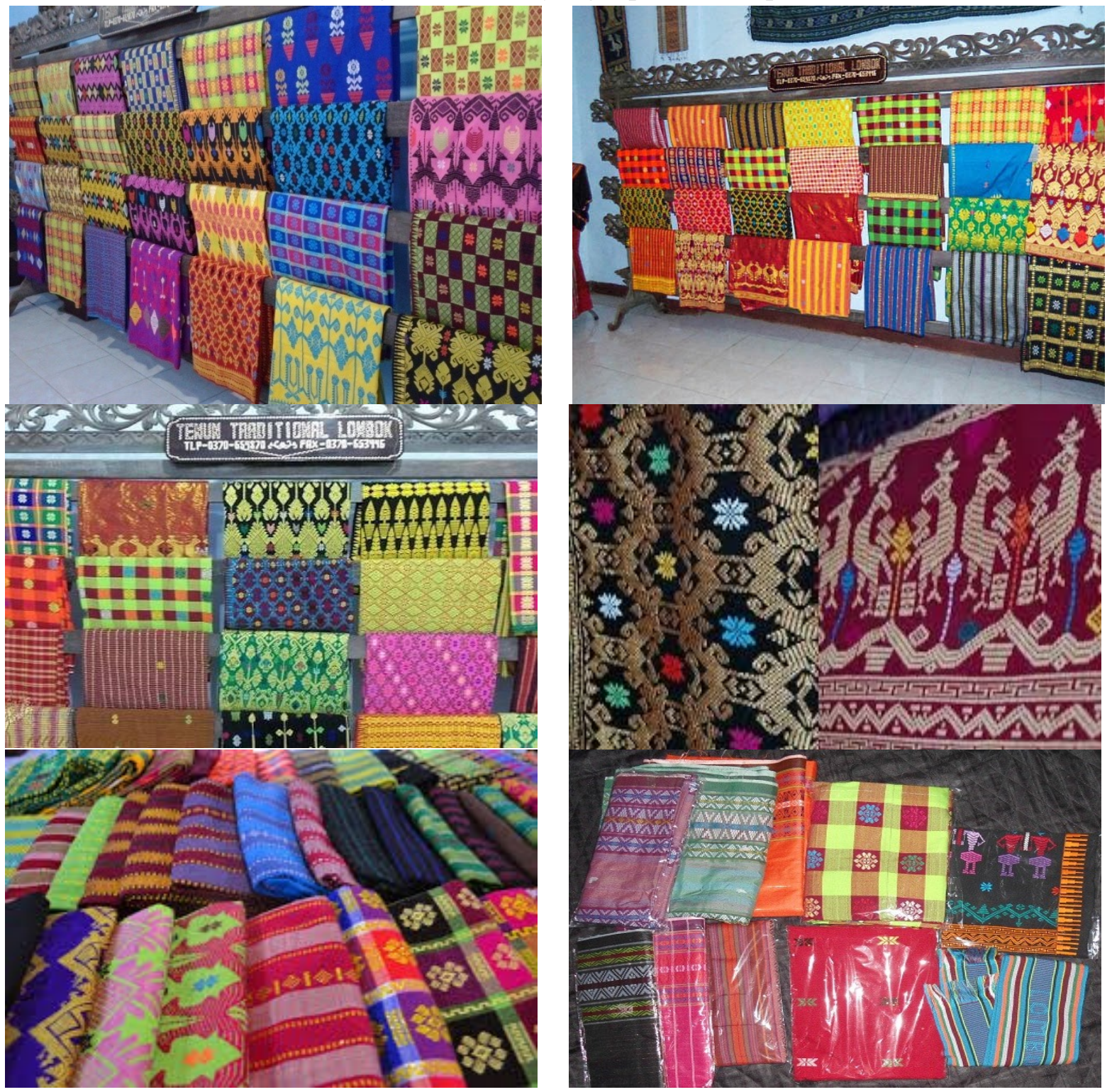

Gambar 3. Kain Tenung Songket Lombok

To Maega, 2(2), Agustus 2019 | 41 


\section{To Maega | Jurnal Pengabdian Masyarakat}

P-ISSN: 2622-6332 \& E-ISSN: 2622-6340

TOMAEGA Volume 2 Nomor 2, Agustus 2019, hlm : 36-43

Untuk terus meningkatkan daya saing UKM serta untuk mendapatkan peluang ekspor dan peluang bisnis lainnya salah satu cara atau strategi yang dapat dilakukan adalah dengan pemanfaatan Teknologi Informasi dan Komunikasi (TIK). Pemanfaatan TIK yang banyak dilakukan adalah e-commerce.Melihat kondisi tersebut dapat dipastikan ke depannya perkembangan e-commerce di Indonesia akan semakin meningkat, hal ini juga dapat berlaku dalam penerapan e-commerce di UKM. Setidaknya ada lima hal mengapa e-commerce dan internet dapat membangun entrepreneurship di suatu Negara berkembang:

1. E-commerce memfasilitasi akses pengerajin dan UKM

2. E-commerce memfasilitasi dalam melakukan promosi dan pengembangan pariwisata Negara-negara berkembang dalam skala global

3. E-commerce memfasilitasi pemasaran produk pertanian di pasar global.

4. E-commerce menyediakan jalan bagi perusahaan-perusahaan di Negara-negara miskin untuk masuk ke dalam rantai suplai B2B dan B2G.

5. E-commerce membantu menyediakan layanan bagi perusahaan-perusahaan di Negara-negara berkembang agar dapat beroperasi lebih efisien dengan langsung memberikan layanan khusus untuk pelanggan internasional.

UKM mempunyai peran yang sangat strategis dalam pembangunan ekonomi di Negaranegara berkembang.Saat ini, UKM sudah dapat meningkatkan pangsa pasar mereka dengan melakukan perdagangan secara eletronik sehingga transaksi dapat dilakukan secara online dan pelanggan dapat berasal dari seluruh belahan dunia.

\section{SIMPULAN DAN SARAN}

Inovasi yang ditargetkan dalam penelitian ini adalah sebuah penerapan e-commerce dalam membantu memasarkan, melakukan promosi dan melakukan pengelolaan penjualan kain tenun songket secara online. E-Commerce merupakan salah satu cara yang dapat dilakukan oleh pelaku Usaha Kecil Menengah (UKM) untuk memasarkan produknya untuk dapat memperluas akses pasar. Pemasaran melalui e-commerce membuat pelaku bisnis Usaha Kecil Menengah dapat langsung berkomunikasi dengan pembelinya sehingga mereka dapat memperoleh keuntungan yang lebih besar.E-commerce untuk pemasaran produk Usaha Kecil Menengah (UKM) dapat memperoleh manfaat serta keuntungan karena lebih murah dan efisien. Selain itu e-commerce juga memiliki akses tanpa batas, saat sebuah bisnis memiliki alamat di internet, apa yang ditampilkan dalam internet dapat diakses oleh pengunjung dari belahan dunia manapun. Diharapkan penelitian ini bisa dikembangkan yang lebih luas lagi dari segi hasil kerajinan yang lainnya yang terdapat di Lombok seperti kerajinan gerabah,cukli,mutiara dan kerajinan lainnya untuk dipromosikan juga melalui E-commerce. 


\section{DAFTAR PUSTAKA.}

Andiani, D. 2012. Strategi Pengembangan KapasitasPengrajin Tenun di Desa Sukarara, Lombok Tengah, NTB. Kementerian pariwisata dan ekonomi kreatif.

Atmosudiro, S, D.S. Nugrahani, Chr. Wisma Nugraha Rich., Sektiadi, 2003. Model Pariwisata Budaya Berbasis Tenun di Lombok. Yogyakarta: UGM.

Atmosudiro, S, dkk. 2005. Model Pariwisata Budaya Berbasis Tenun di Lombok. Yogyakarta: UGM.

Fizrian, Destika. 2015. Perkembangan Jumlah Tenaga Kerja di UKM.http://destikafizriani.blogspot.co.id/2015/05/perkembangan-jumlah-tenaga-kerja-diukm.html diakses pada 18 april 2016

Fuady, Munir/ 2005. Pengantar Hukum Bisnis: Menata Bisnis Modern di Era Globalisasi, Edisi ke dua, Bandung: PT Citra Aditya Bakti.

Kominfo. 2014. Pengguna Internet di Indonesia Capai 82 Juta. https://kominfo.go.id/index.php/content/detail/3980/Kemkominfo\%3A+Pengguna+Internet + di+Indonesia+Capai+82+Juta/0/berita_satker diakses pada tanggal 18 april 2016

Nofie, Imam. 2007. Mengenal E-Commerce .www.nofieimam.com diakses pada 18 april 2016

Norhandayani. 2011.

Pengertian

Kearifan Lokal.http://naninorhandayani.blogspot.co.id/2011/05/pengertian-kearifan-lokal.html diakses pada tanggal 25 April 2016)

Ridwan, N.A., Landasan Keilmuan Kearifan Lokal. Jurnal Studi Islam dan Budaya, 2007, Vol 5, (1), 27-38

Turban E, JE Aronson. 2001. Decision Support Systems and Intellegent Systems. New Jersey: Prentice Hall 